\title{
Penicillin prophylaxis in children with sickle cell disease in Brent
}

\author{
David Cummins, Robert Heuschkel, Sally C Davies
}

\begin{abstract}
Objective-To assess compliance with oral penicillin prophylaxis in children with sickle cell disease and identify possible reasons for poor compliance.

Design-Closed questionnaires given to parents of children with sickle cell disease and general practitioners in Brent. Urine samples from 23 children were tested for penicillin.
\end{abstract}

Setting-Paediatric haematology clinic, Central Middlesex Hospital, and general practices in Brent.

Subjects -50 children (aged $\leqslant 16)$ attending clinic with sickle cell disease over six months ( 33 HbSS, $12 \mathrm{HbSC}$, five HbS $\beta$ thalassaemia). 30 general practitioners: 15 with the greatest number of patients with sickle cell disease on the Brent register; 15 selected randomly from family practitioner committee's list.

Main outcome measures-Reported compliance with and awareness of importance of penicillin prophylaxis. Results of urine tests for penicillin.

Results -31 parents claimed that their children received penicillin every day and 19 that they received it most days ( $\geqslant 5$ days a week). Penicillin was detected in only 10 of 23 urine samples tested. Parents and doctors seemed not to appreciate the importance of treatment: only eight parents were aware of the risk of death if penicillin were discontinued, and 16 doctors were unaware that regular penicillin prophylaxis prevents pneumococcal septicaemia and death in these children.

Conclusions-Education for families with children with sickle cell disease must be improved. Specialised information and training are needed for doctors working in areas with a high prevalence of the disorder.

\section{Introduction}

Infection, particularly with Streptococcus pneumoniae, is an important cause of morbidity and death in patients with sickle cell disease. ${ }^{\prime 2}$ The risk of pneumococcal meningitis in such patients is estimated to be 600 times that in the general population, ${ }^{3}$ with $90 \%$ of cases occurring in the first three years of life. ${ }^{4}$ Introducing a pneumococcal vaccine failed to reduce appreciably the mortality from pneumococcal sepsis, partly because suboptimal antibody responses in patients aged less than 2 years mean that protection is inadequate when the children are at greatest risk. ${ }^{5}$

In 1986 Gaston et al reported reduced pneumococcal infection and related deaths in children with sickle cell disease given regular penicillin prophylaxis. ${ }^{2}$ They recommended that all children should be screened for the disease at birth and that those affected should commence penicillin prophylaxis before 4 months of age. Other studies endorsed this view. ${ }^{67}$

Despite widespread agreement over the necessity for prophylaxis, however, ${ }^{8}$ little is known about the awareness of this necessity among parents and general practitioners of children with sickle cell disease or about patients' compliance with penicillin treatment. We investigated these issues among families and general practitioners in Brent.

\section{Subjects and methods}

Background-Our paediatric haematology outpatient clinic was established in 1984. Counsellors from the Brent Sickle Cell Centre attend the clinic and undertake home visits when appropriate. Parents of children with newly diagnosed sickle cell disease are told about the necessity for penicillin prophylaxis by a doctor and a counsellor. An initial letter to the general practitioner explains the need for prophylaxis and advises about increments in penicillin dose. This information is reinforced to parents and general practitioners at subsequent (four to six monthly) outpatient visits.

Patient study-At the time of the study, 89 children with sickle cell disease (age $\leqslant 16$ years) were being followed up at the clinic. The parents of 50 children attending over six months were interviewed with a closed questionnaire. Table I gives the ages and genotypes of these children. A urine sample was requested from all children; 23 provided a specimen.

TABLE I-Genotype and age of children in study (all children attending haematology clinic) with sickle cell disease

\begin{tabular}{lcccc}
\hline & \multicolumn{3}{c}{ Age (years) } & \\
\cline { 2 - 4 } Genotype $^{\star}$ & $\leqslant 2$ & -10 & -16 & Total \\
\hline SS & $3(15)$ & $22(23)$ & $8(13)$ & $33(51)$ \\
SC & $3(10)$ & $5(9)$ & $4(11)$ & $12(30)$ \\
S $\beta$ thal & $2(5)$ & $1(1)$ & $2(2)$ & $5(8)$ \\
\hline All patients & $8(30)$ & $28(33)$ & $14(26)$ & $50(89)$ \\
\hline
\end{tabular}

$\star S=$ sickle cell, $C=$ normal,$\beta$ thal $=\beta$ thalassaemia.

Specimens were tested for the presence of penicillin by examining $\beta$ lactamase sensitive inhibition of a penicillin sensitive Staphylococcus aureus colony in culture. This technique reliably detects penicillin in urine for at least five hours after a single dose (S Shafi, S C Davies, unpublished data). ${ }^{9}$

General practitioner study-Thirty Brent general practitioners were visited and asked to complete a closed questionnaire. Fifteen (group 1) were selected because their lists had the greatest number of patients with sickle cell disease, as determined from the Brent sickle cell disease register ${ }^{10} ; 15$ (group 2) were selected randomly from the family practitioner committee's list of general practitioners in Brent.

\section{Results}

PATIENT STUDY

Of the parents interviewed, $31(62 \%)$ claimed that their children received penicillin every day; the

Correspond
Dr Davies. 
remainder claimed that they received it most $(\geqslant 5)$ days a week. Penicillin was detected, however, in only $10(47 \%)$ of 23 urine samples analysed.

Most parents (42) experienced no problems in obtaining repeat prescriptions or with having them dispensed, and the penicillin was generally well tolerated: only three parents claimed that their child objected to taking the drug.

Parents of children aged over 2 were asked when penicillin prophylaxis had been commenced. Only eighteen were certain it had been initiated in the first year of life; 16 said that it had been commenced at a mean (SD) age of $3.7(2 \cdot 6)$ years; eight were uncertain when it had been started.

All but four parents remembered receiving an explanation about the need for penicillin prophylaxis (table II). Nearly a third, however, did not appreciate that the aim of prophylaxis was to prevent infection, and, although all but six thought their children should take penicillin regularly, many seriously underestimated the risks of discontinuing treatment (table II).

\section{GENERAL PRACTITIONER STUDY}

Doctors selected because their lists had high numbers of children with sickle cell disease (group 1) estimated that they had a mean (SD) of $8 \cdot 8(7 \cdot 5)$ such children on their list; the doctors in group 2 estimated $1.4(1.5)$ children. The total number of children estimated by the 30 doctors was 134, whereas only 89 were actually listed on the Brent register. One doctor in group 1 and five in group 2 claimed to have no children with sickle cell disease registered, and only 11 of the other doctors were aware of prescribing regular penicillin prophylaxis.

Doctors' knowledge about sickle cell disease was generally poor, with no significant differences observed between doctors in groups 1 and 2 . Twenty two knew that children with sickle cell disease had an increased risk of infection, but 10 were unsure why this was so and only one knew that they developed functional asplenia. Twenty four were unaware of such children's susceptibility to pneumococcal infection, and $16 \mathrm{did}$ not know that regular penicillin prophylaxis prevents septicaemia and death. The doctors were, however, well acquainted with the services available for children with sickle cell disease in Brent (table III).

\section{Discussion}

We found that compliance with penicillin prophylaxis was poor, with penicillin being detected in

TABLE II -Responses of parents to questions on penicillin prophylaxis for sickle cell disease

\begin{tabular}{lc}
\hline & $\begin{array}{c}\text { No of parents } \\
(\mathbf{n}=50)\end{array}$ \\
\hline Who explained need for prophylaxis: & \\
No memory of explanation & 4 \\
General practitioner & 4 \\
Counsellor for sickle cell disease & 9 \\
$\quad$ Consultant & 33 \\
Consequences of discontinuing penicillin: & 3 \\
None & 10 \\
Unsure & $37(8)$ \\
Child could become ill (or die) &
\end{tabular}

TABLE III-General practitioners' awareness of Brent services for children with sickle cell disease

\begin{tabular}{lc}
\hline & $\begin{array}{c}\text { No aware } \\
(\mathrm{n}=30)\end{array}$ \\
\hline Brent Sickle Cell Centre & 24 \\
Antenatal diagnosis or counselling & 24 \\
Neonatal screening programme & 22 \\
Specialist clinic at Central Middlesex Hospital & 16 \\
\hline
\end{tabular}

only $47 \%$ of the urine samples tested. Similar levels of compliance have been reported in other patients receiving long term penicillin treatment. ${ }^{11-13}$ Parents reported little difficulty in obtaining repeat prescriptions and the drug was generally well tolerated, but the disparity between the compliance reported by parents and that determined by urine testing suggests that some children may not have consumed the penicillin given to them. We now advise parents to supervise penicillin ingestion. Gordis et $a l^{14}$ showed that in children with rheumatic fever severity of symptoms was the only factor positively correlating with compliance. Children with sickle cell disease typically have periods of pain free good health interspersed with infections and painful vaso-occlusive crises; if compliance is determined mainly by disease activity it may be difficult to improve.

Parents do not fully appreciate the importance of prophylaxis, many seriously underestimating the risks of discontinuing treatment. Their knowledge might be improved by providing frequent home visits by specially trained nurse counsellors. Such counsellors can provide a valuable contribution to the standard medical team and are ideally placed to provide advice and education for patients and their families. Financial support is required to ensure these posts are established nationally..$^{1516}$

Most of the general practitioners interviewed did not prescribe penicillin prophylaxis for children with sickle cell disease, and this seemed to stem from inadequate knowledge of the disease and its complications. They were, however, well acquainted with the services available in Brent, and some may have partially neglected their responsibilities because of the specialist services available.

Further studies must be undertaken to define the optimal ways of counselling families of children with sickle cell disease and improving general practitioners' knowledge about the disease; otherwise the advantages that should accrue from neonatal screening programmes will be greatly diminished.

We thank the patients and their families; our nurse counsellors; Dr S Shafi for urine testing; and Dr M Brozovic for critical review of the manuscript.

1 Anonymous. Penicillin prophylaxis for habies with sickle cell anaemia Editorial.) Lancet 1986;ii:1432-3.

2 Gaston $\mathrm{MH}$, Verter JI, Woods G, et al. Prophylaxis with oral penicillin in children with sickle cell anemia. A randomised trial. $N$ Engl $f$ Med 1986;314:1593-9.

3 Barrett-Connor E. Bacterial infections in sickle cell anemia. An analysis of 250 infections in 166 patients and a review of the literature. Medicine 1971;50 97-108.

4 Robinson $\mathrm{MG}$, Watson RJ. Pneumococcal meningitis in sickle cell anemia N Englf Med 1966;274:1006-8.

5 John AB, Ramlal A, Jackson H, Maude HG, Sharma AW, Sergeant GR Prevention of pneumococcal infection in children with homozygous sickle cell anaemia. $B M J$ 1984;288:1567-70.

6 Rowley P'T. Newborn screening for sickle cell disease. Benefits and burdens. N Y State I Med 1978;78:42-4

7 Brown AK, Miller ST, Agatisa P. Care of infants with sickle cell disease. Pediatrics 1989:83:897-900.

8 Powars D, Overtuf G. Penicillin in sickle cell anemia. Am $\mathcal{J}$ Dis Child 1987;141:250-2.

9 Grove DC, Randall WA. Assay methods of antibiotics: a laboratory manual. New York: Medical Encyclopaedia, 1955:14.

10 Brozovic $M$, Anionwu E. Sickle cell disease in Britain. $f$ Clin Pathol 1984;37:1321-6.

11 Gordis L, Markowitz M, Lillienfield AM. Studies in the epidemiology and preventability of rheumatic fever. IV. A quantitative determination of compliance in children on oral penicillin prophylaxis. Pediatrics 1969;43 173-9.

12 Milne RIG. Assessment of care of children with sickle cell disease: implication for neonatal screening programmes. BMf 1990;300:371-4.

13 Buchanan GR, Siegel JD, Smithj SJ, de Passe B. Oral penicillin prophylaxis in children with impaired splenic function: a study of compliance. Pediatric 1982;70:926-33.

14 Gordis L, Markowitz M, Lillienfield AM. Why patients don't follow medical advice: A study of children on long-term antistreptococcal prophylaxis. f Pediatr 1969;75:957-68

15 Franklin IM. Services for sickle cell disease: unified approach needed. $B M 7$ 1988;296:592.

16 Prashar U, Anionwu E, Brozovic M. Sickle cell anaemia-who cares? London: Runnymede Trust, 1985.

(Accepted 27 February 1991) 